\title{
How much Fear of COVID-19 is There in Latin America? A Prospective Exploratory Study in Six Countries
}

\author{
Jeel Moya-Salazar ${ }^{1,2^{\star}}$, Betsy Cañari ${ }^{2}$, Hans Contreras-Pulache ${ }^{2^{\star \star}}$
}

\author{
${ }^{1}$ Hospital Nacional Docente Madre Niño San Bartolomé, Lima, PERU \\ ${ }^{2}$ Faculties of Health Science, Universidad Norbert Wiener, Lima, PERU \\ *Corresponding Author: jeel.moya@gmail.com \\ *^Corresponding Author: hans.contreras@uwiener.edu.pe
}

Citation: Moya-Salazar J, Cañari B, Contreras-Pulache H. How much Fear of COVID-19 is There in Latin America? A Prospective Exploratory Study in Six Countries. Electron J Gen Med. 2022;19(1):em339. https://doi.org/10.29333/ejgm/11401

\section{ARTICLE INFO}

Received: 8 Sep. 2021

Accepted: 16 Oct. 2021

\section{ABSTRACT}

Introduction: During the unprecedented lockdown, COVID-19 is causing people to suffer from mental disorders in response to strict containment measures. Latin America is the third most severely affected continent, and restrictive measures can have many negative effects on mental health (such as anxiety, depression, and stress) that may arise with fear. We aimed to measure the spread of fear of COVID-19 in the Latin American population.

Materials and Methods: We conducted a prospective study in 535 participants of six countries of Latin America (Argentina, Bolivia, Colombia, Guatemala, Mexico, and Peru), and a country of Europe (Spain) as a control, during 2020. We used the Fear of COVID-19 Scale.

Results: The mean age was $31.2 \pm 13.2$ years $(70.8 \%$ under 30 years) and the majority were women $(57.9 \%)$ and $76.6 \%$ had a technical, university, or postgraduate studies. Seven percent of participants had high rates of fear of COVID-19, these high estimates of fear were observed in Argentines (14.3\%, score range: $28-31 \%)$, of Peruvians (10.2\%, score range: $27-35 \%)$, and Mexicans (5.7\%, score range: $27-29 \%)$. Both Peru $(p=0.003)$ and Mexico $(p=0.0001)$ showed significant differences from the control country. We showed low levels of fear in $57.1 \%, 45.5 \%$, $42.9 \%$, and $41.2 \%$ of Argentines, Colombians, Bolivians, and Peruvians, respectively. No differences in low levels of fear we found among age groups ( $p>0.05)$, however, we find differences between genders $(p=0.001)$.

Conclusions: These results suggested low levels of fear in six Latin American countries, highlighting the need to contextualize fear behavior as a key element in people's psychological well-being and mental health during the COVID-19 pandemic.

Keywords: COVID-19, fear, Latin America, mental health, SARS-CoV-2

\section{INTRODUCTION}

Currently, the outbreak of new coronavirus disease (COVID19) has successfully spread worldwide, so its spread strongly affects mental and global health. SARS-CoV-2 has been shaking the world for almost two years, and its distribution has begun to spread from Asia to other continents, stagnating with high mortality rates in certain regions such as the Americas. On February 25th of 2020, Brazil was the first country from Latin America that reported a case of SARS-CoV-2, followed by similar cases in most countries [1,2] where countermeasures were implemented against the spread of the disease as soon as the "zero" patient was detected.

A notorious fear has been raised due to some countries where measures were delayed either due to a misconception of the severity of the disease or to the concern of the effects on the country's economy [3,4]. As COVID-19 has spread in the region we can observe that some countries have suffered a higher impact than others due to series of factors are affecting communities' mental health, as the inequality in the provision of healthcare services and lack of personal protective equipment, the quarantine, social distancing and the restrictions that have produced an increase in domestic violence [5], the massive loss of jobs or the urgency for providing families with food from householders who survive on their daily income [6-9].

Like a pandemic, COVID-19 alone is a reason to generate concern and fear among people, yet, this is aggravated when some sectors have to worry about how it is affecting also their economy, education, or personal relationships, which raise the probability of negative outcomes including domestic violence and suicidal thoughts $[10,11]$. This has been already seen and studied in regions where the pandemic has spread earlier, with the notable effort of Ahorsu et al. [12] who developed a scale to measure the fear generated in that region. Then, research on fear of COVID-19 has been extended to various regions, including Brazil, Argentina, and Peru in Latin America $[13,14]$. These studies have verified their own "Fear of COVID-19 Scale" (FCV-19S) among the affected population, but they have not focused on analyzing the extent of region-wide fear, since fear may vary considerably in each population.

FCV-19S result useful to understand the mental health of a population and provide with measures to prevent the development of mental illness (as anxiety, depression, etc.), which can give rise increment the cases of violent outcomes in a region as Latin America that has been declared to have the higher levels of violence worldwide [15]. 
Table 1. Demographic characteristics according to the country of residence of the population studied

\begin{tabular}{|c|c|c|c|c|c|c|c|c|}
\hline \multirow[b]{2}{*}{ Characteristics } & \multicolumn{7}{|c|}{ Countries } & \multirow[b]{2}{*}{ p-value } \\
\hline & $\begin{array}{c}\text { Argentina } \\
(\mathrm{n}=56)\end{array}$ & Bolivia ( $n=28$ ) & $\begin{array}{c}\text { Colombia } \\
(n=66)\end{array}$ & Spain $(n=50)$ & $\begin{array}{c}\text { Guatemala } \\
(n=20)\end{array}$ & Mexico $(n=70)$ & $\overline{\text { Peru }(n=245)}$ & \\
\hline \multicolumn{9}{|l|}{ Age group } \\
\hline$<20(n=46)$ & $0(0)$ & $4(14.3)$ & $2(3)$ & $0(0)$ & $4(20)$ & $2(2.9)$ & $34(13.9)$ & \multirow{5}{*}{0.089} \\
\hline $21-30(n=333)$ & $22(39.3)$ & $16(57.1)$ & $34(51.5)$ & $40(80)$ & $10(50)$ & $60(857)$ & $151(61.6)$ & \\
\hline $31-40(n=50)$ & $2(3.6)$ & $0(0)$ & $16(24.2)$ & $0(0)$ & $0(0)$ & $8(11.4)$ & $24(9.8)$ & \\
\hline $41-50(n=43)$ & $14(25)$ & $2(7.1)$ & $6(9.1)$ & $0(0)$ & $6(30)$ & $0(0)$ & $15(6.1)$ & \\
\hline$>50(n=63)$ & $18(32.1)$ & $6(21.4)$ & $8(12.1)$ & $10(20)$ & $0(0)$ & $0(0)$ & $21(8.6)$ & \\
\hline \multicolumn{9}{|l|}{ Sex } \\
\hline Male & $12(21.4)$ & $12(42.9)$ & $46(69.7)$ & $38(76.0)$ & $8(40.0)$ & $32(45.7)$ & $103(42.0)$ & \multirow{2}{*}{0.071} \\
\hline Female & $44(78.6)$ & $16(57.1)$ & $20(30.3)$ & $12(24.0)$ & $12(60.0)$ & $38(54.3)$ & $142(58.0)$ & \\
\hline \multicolumn{9}{|l|}{ Degree of instruction } \\
\hline High school & $16(28.6)$ & $4(14.3)$ & $4(6.1)$ & $4(8.0)$ & $0(0)$ & $4(5.7)$ & $33(13.4)$ & \multirow{4}{*}{-0.004} \\
\hline Technical & $16(28.6)$ & $2(7.1)$ & $2(2.0)$ & $2(4.0)$ & $0(0)$ & $6(8.6)$ & $36(14.7)$ & \\
\hline Undergraduate & $12(21.4)$ & $16(57.1)$ & $40(60.6)$ & $16(32.0)$ & $20(100)$ & $52(74.3)$ & $146(59.6)$ & \\
\hline Postgraduate & $12(21.4)$ & $6(21.4)$ & $20(30.3)$ & $28(56)$ & $0(0)$ & 8 (11.4) & $30(12.2)$ & \\
\hline
\end{tabular}

The main objective of this study was to measure the spread of fear of COVID-19 in the Latin American population. The study hypotheses included (a) that fear of COVID-19 would be variably distributed among Latin American countries and (b) that fear of Latin American countries could vary when compared to European countries that have already experienced COVID-19. Since no study, to the best of our knowledge, has examined such a relationship between these concepts, it is certainly interesting to estimate the FCV-19S fear.

\section{MATERIALS AND METHODS}

\section{Participants and Countries}

We designed an exploratory prospective cohort study based on a questionnaire during 2020. Between March 25 and April 31, 535 individuals of seven countries were surveyed with FCV-19S. We include six countries of Latin America (Argentina, Bolivia, Colombia, Guatemala, Mexico and Peru), and a country of Europe (Spain) as a control.

\section{Fear of COVID-19 Scale (FCV-19S)}

The FCV-19S scale is a seven-item self-report measure that has a Likert scale score ( $1=$ strongly disagree and $5=$ strongly agree), which has been created by Ahorsu et al. [12] during the first wave in 2020. To quantify the fear, the scores for each question are added, so the higher the score, the higher the level of fear of COVID-19. (Additional file 1) This measure has been validated in more than 12 countries worldwide [14,16-20]. This adequate performance of the FCV-19S has also been seen in Argentina [21,22], Colombia [23], Mexico [24], and Peru [25,26].

\section{Data Collection}

Participants were recruited voluntarily via email lists and were invited to partake in the study. All surveys were virtual through Google Form (Google, CA, US), and informed consent has been provided before the survey (first page of the online survey). Participants were informed of the purpose of the study, its limitations, and the benefits they would receive from agreeing to participate. In addition, they were informed that the survey is anonymous and that the data will be handled with great reliability for the study and that it will be eliminated after its analysis.

\section{Data Analysis}

The initial data analysis includes verification of the online data collected by two authors, then the Kolmogorov-Smirnov normality test was performed. The demographic variables included were age, gender, and level of education, which were analyzed using descriptive statistics. To interpret the levels of fear, the instructions of the FCV-19S [12] were followed. The differences in fear levels between countries were performed with one-way ANOVA considering a $p$-value $<0.05$ as significant. Data analysis was performed in IBM SPSS v25.0 (Armonk, US) for Windows.

\section{Ethical Aspects}

This study was undertaken in accordance with the Declaration of Helsinki. This study was approved by the Ethics Committee of the Norbert Wiener University (FCE-RRR-COVID2020.03-01).

\section{RESULTS}

The mean age was $31.2 \pm 13.2$ years ( $\mathrm{Cl} 95 \% 30.1$ to 32.2 ), with $70.8 \%$ (379 individuals) under 30 years of age. Furthermore, the majority were women (57.9\%), and 470 (76.6\%) had a technical, university, or postgraduate studies. We found no differences in demographic features between populations (Table 1).

In general, 41 (7.7\%) had high rates of fear of COVID-19. These high estimates of fear were observed in $14.3 \%$ of Argentines (score range: $28-31 \%$ ), $10.2 \%$ of Peruvians (score range: $27-35 \%$ ), and $5.7 \%$ of Mexicans (score range: $27-29 \%$ ) (Figure 1). Both Peru $(p=0.003)$ and Mexico $(p=0.0001)$ showed significant differences from the control country Spain. Nine percent (31 individuals) of women and $4.4 \%$ (10 individuals) of men had a high fear of COVID-19. In addition, 6.9\% (26 individuals) and $7.9 \%$ (5 individuals) of participants $\leq 30$ and $>50$ years had high rates of fear of COVID-19, respectively.

FCV-19S inter-items showed differences between the countries evaluated $(p<0.001)$. In all the items the comparison group (Spain) had significant differences, mainly with Peru $(p<0.001)$. On average, $30 \%$ of participants agreed with "being very afraid of the coronavirus" and $26 \%$ agreed with "being afraid of losing their life due to coronavirus" (Table 2). Low estimates were shown on the characteristics of anxiety and 


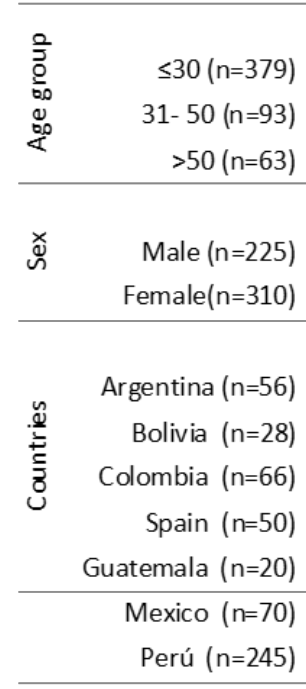

Fear Low/moderate

$$
\begin{gathered}
176(46.4) \\
41(44.1) \\
30(47.6)
\end{gathered}
$$

$156(45.7)$

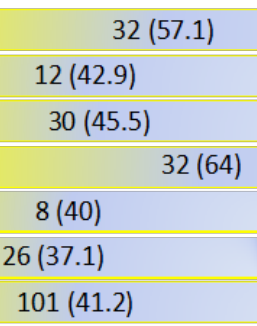

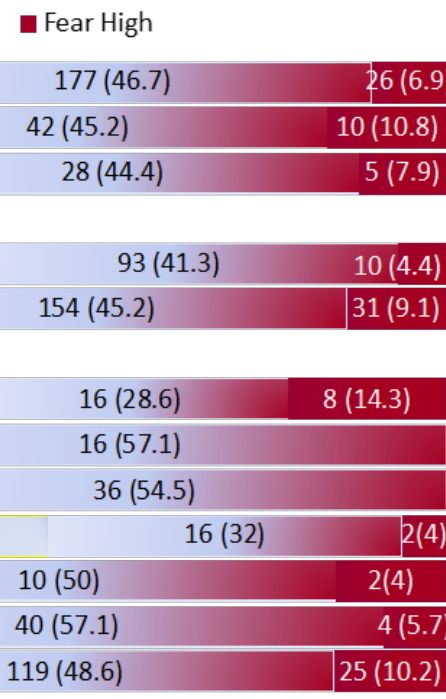

\begin{tabular}{|c|c|c|c|c|c|c|c|}
\hline $\begin{array}{l}\text { Fear of COVID-19 } \\
\text { Items }\end{array}$ & Countries & $\begin{array}{l}\text { Strongly } \\
\text { Disagree }\end{array}$ & Disagree & Neutral & Agree & $\begin{array}{l}\text { Strongly } \\
\text { Agree }\end{array}$ & p-value \\
\hline \multirow{7}{*}{$\begin{array}{c}\text { I am most afraid of } \\
\text { Corona }\end{array}$} & Argentina & $8(14.3)$ & $16(28.6)$ & $8(14.3)$ & $20(35.7)$ & $4(7.1)$ & \multirow{7}{*}{0.0001} \\
\hline & Bolivia & $2(7.1)$ & $12(42.9)$ & $4(14.3)$ & $8(28.6)$ & $2(7.1)$ & \\
\hline & Colombia & $6(9.1)$ & $10(15.2)$ & $16(24.2)$ & $30(45.5)$ & $4(6.1)$ & \\
\hline & Spain & $18(36)$ & $10(20)$ & $10(20)$ & $10(20)$ & $2(4)$ & \\
\hline & Guatemala & $2(10)$ & $2(10)$ & $4(20)$ & $10(50)$ & $2(10)$ & \\
\hline & Mexico & $4(5.7)$ & $12(17.1)$ & $28(40)$ & $20(28.6)$ & $6(8.6)$ & \\
\hline & Perú & $17(6.9)$ & $36(14.7)$ & $66(26.9)$ & $97(39.6)$ & $29(11.8)$ & \\
\hline \multirow{7}{*}{$\begin{array}{l}\text { It makes me } \\
\text { uncomfortable to } \\
\text { think about Corona }\end{array}$} & Argentina & $10(17.9)$ & $14(25.0)$ & $10(17.9)$ & $14(25.0)$ & $8(14.3)$ & \multirow{7}{*}{0.002} \\
\hline & Bolivia & $8(28.6)$ & $4(14.3)$ & $8(28.6)$ & $6(21.4)$ & $2(7.1)$ & \\
\hline & Colombia & $4(6.1)$ & $14(21.2)$ & $12(18.2)$ & $26(39.4)$ & $10(15.2)$ & \\
\hline & Spain & $16(32)$ & $14(28)$ & $8(16)$ & $8(16)$ & $4(8)$ & \\
\hline & Guatemala & $2(10)$ & $4(20)$ & $6(30)$ & $6(30)$ & $2(10)$ & \\
\hline & Mexico & $8(11.4)$ & $14(20.0)$ & $22(31.4)$ & $18(25.7)$ & $8(11.4)$ & \\
\hline & Peru & $21(8.6)$ & $71(29.0)$ & $51(20.8)$ & $71(29.0)$ & $31(12.7)$ & \\
\hline \multirow{7}{*}{$\begin{array}{l}\text { My hands become } \\
\text { clammy when I think } \\
\text { about Corona }\end{array}$} & Argentina & $34(60.7)$ & $18(32.1)$ & $2(3.6)$ & $2(3.6)$ & $0(0)$ & \multirow{7}{*}{0.0001} \\
\hline & Bolivia & $10(35.7)$ & $16(57.1)$ & $2(7.1)$ & $0(0)$ & $0(0)$ & \\
\hline & Colombia & $40(60.6)$ & $22(33.3)$ & $4(6.1)$ & $0(0)$ & $0(0)$ & \\
\hline & Spain & $36(72)$ & $10(20)$ & $2(4)$ & $0(0)$ & $2(4)$ & \\
\hline & Guatemala & $8(40)$ & $10(50)$ & $0(0)$ & $2(10)$ & $0(0)$ & \\
\hline & Mexico & 30 (42.9) & $24(34.3)$ & $14(20)$ & $2(2.9)$ & $0(0)$ & \\
\hline & Peru & $100(40.8)$ & $97(39.6)$ & $27(11)$ & $16(6.5)$ & $5(2)$ & \\
\hline \multirow{7}{*}{$\begin{array}{c}\text { I am afraid of losing } \\
\text { my life because of } \\
\text { Corona }\end{array}$} & Argentina & $10(17.9)$ & $20(35.7)$ & $8(14.3)$ & $6(10.7)$ & $12(21.4)$ & \multirow{7}{*}{0.001} \\
\hline & Bolivia & $2(7.1)$ & $10(35.7)$ & $6(21.4)$ & $4(14.3)$ & $6(21.4)$ & \\
\hline & Colombia & $10(15.2)$ & $12(18.2)$ & $14(21.2)$ & $24(36.4)$ & $6(9.1)$ & \\
\hline & Spain & $22(44)$ & $14(28)$ & $12(24)$ & $0(0)$ & $2(4)$ & \\
\hline & Guatemala & $0(0)$ & $2(10)$ & $10(50)$ & $8(40)$ & $0(0)$ & \\
\hline & Mexico & $16(22.9)$ & $14(20.0)$ & $18(25.7)$ & $22(31.4)$ & $0(0)$ & \\
\hline & Peru & 35 (14.3) & $57(23.3)$ & $47(19.2)$ & $68(27.8)$ & $38(15.5)$ & \\
\hline \multirow{7}{*}{$\begin{array}{l}\text { When I watch news } \\
\text { and stories about } \\
\text { Corona on social } \\
\text { media, I become } \\
\text { nervous or anxious }\end{array}$} & Argentina & $12(21.4)$ & $14(25.0)$ & $10(17.9)$ & $8(14.3)$ & $12(21.4)$ & \multirow{7}{*}{0.004} \\
\hline & Bolivia & $4(14.3)$ & $8(28.6)$ & $10(35.7)$ & $4(14.3)$ & $2(7.1)$ & \\
\hline & Colombia & $10(15.2)$ & $12(18.2)$ & $20(30.3)$ & $22(33.3)$ & $2(3.0)$ & \\
\hline & Spain & $24(48)$ & $6(12)$ & $12(24)$ & $6(12)$ & $2(4)$ & \\
\hline & Guatemala & $2(10)$ & $4(20)$ & $0(0)$ & $14(70)$ & $0(0)$ & \\
\hline & Mexico & $14(20.0)$ & $18(25.7)$ & $16(22.9)$ & $18(25.7)$ & $4(5.7)$ & \\
\hline & Peru & $45(18.4)$ & $67(27.3)$ & $52(21.2)$ & $64(26.1)$ & $17(6.9)$ & \\
\hline \multirow{7}{*}{$\begin{array}{l}\text { I cannot sleep } \\
\text { because I'm worrying } \\
\text { about getting Corona }\end{array}$} & Argentina & $26(46.4)$ & $16(28.6)$ & $4(7.1)$ & $8(14.3)$ & $2(3.6)$ & \multirow{7}{*}{0.003} \\
\hline & Bolivia & $16(57.1)$ & $6(21.4)$ & $4(14.3)$ & $2(7.1)$ & $0(0)$ & \\
\hline & Colombia & $34(51.5)$ & $18(27.3)$ & $12(18.2)$ & $2(3.0)$ & $0(0)$ & \\
\hline & Spain & $34(68)$ & $14(28)$ & $0(0)$ & $0(0)$ & $2(4)$ & \\
\hline & Guatemala & $8(40)$ & $4(20)$ & $0(0)$ & $8(40)$ & $0(0)$ & \\
\hline & Mexico & $32(45.7)$ & $24(34.3)$ & $12(17.1)$ & $2(2.9)$ & $0(0)$ & \\
\hline & Peru & $95(38.8)$ & $92(37.6)$ & $30(12.2)$ & $20(8.2)$ & $8(3.3)$ & \\
\hline
\end{tabular}

Figure 1. Distribution of fear by age, sex and country of residence of the population studied

Table 2. Baseline distribution of fear in the seven countries included in the study 
Table 2 (continued). Baseline distribution of fear in the seven countries included in the study

\begin{tabular}{|c|c|c|c|c|c|c|c|}
\hline $\begin{array}{c}\text { Fear of COVID-19 } \\
\text { Items }\end{array}$ & Countries & $\begin{array}{l}\text { Strongly } \\
\text { Disagree }\end{array}$ & Disagree & Neutral & Agree & $\begin{array}{c}\text { Strongly } \\
\text { Agree }\end{array}$ & p-value \\
\hline \multirow{7}{*}{$\begin{array}{l}\text { My heart races or } \\
\text { palpitates when I } \\
\text { think about getting } \\
\text { Corona }\end{array}$} & Argentina & $22(39.3)$ & $18(32.1)$ & $2(3.6)$ & $12(21.4)$ & $2(3.6)$ & \multirow{7}{*}{0.0001} \\
\hline & Bolivia & $12(42.9)$ & $8(28.6)$ & $2(7.1)$ & $6(21.4)$ & $0(0)$ & \\
\hline & Colombia & $22(33.3)$ & $14(21.2)$ & $24(36.4)$ & $6(9.1)$ & $0(0)$ & \\
\hline & Spain & $38(76)$ & $8(16)$ & $2(4)$ & $0(0)$ & $2(4)$ & \\
\hline & Guatemala & $8(40)$ & $10(50)$ & $0(0)$ & $0(0)$ & $2(10)$ & \\
\hline & Mexico & $30(42.9)$ & $14(20.0)$ & $18(25.7)$ & $8(11.4)$ & $0(0)$ & \\
\hline & Peru & $72(29.4)$ & $83(33.9)$ & $48(19.6)$ & $30(12.2)$ & $12(4.9)$ & \\
\hline
\end{tabular}

depression, where on average $43 \%$ of the participants strongly disagreed about "my heart races or palpitates when I think about getting Corona", while $50 \%$ of the participants strongly disagreed with each "my hands become clammy when I think about Corona" and "cannot sleep because I'm worrying about getting Corona".

Finally, our findings showed low levels of fear in $57.1 \%$, 45.5\%, 42.9\%, and $41.2 \%$ of Argentines, Colombians, Bolivians, and Peruvians, respectively. We found no differences in low levels of fear between age groups ( $p>0.05)$, however, we find differences between genders $(p=0.001)$.

\section{DISCUSSION}

This study reports a low rate of fear of COVID-19 in Latin American populations in lockdown during 2020. Likewise, related to the comparison group (Spain) we evidenced a significant inter-item difference with countries with a report of high fear of coronavirus (as Mexico and Peru), suggesting that fear could be an independent factor not-related to mortality and morbidity rates due to COVID-19.

The strengths of this exploratory study were that it 's one of the first to report a quantified level of fear assessment in several countries in Latin America during the peak of the pandemic using validated measures. The results emphasize the low fear of COVID-19 perceived by Latin American individuals disagreeing with previous studies [6,15,18,23,27]. These results are possible since the people that were analyzed didn't have COVID-19 or any flu-related symptoms, this is consistent with previous observations that showed that healthy individuals increased their fear scores when they suspected COVID-19 or when they already developed the disease.

Low fear rates may be due to the inclusion of a literate population and also because they were young adults as has recently been reported in the Indian population [28]. Although the relationship between age and fear has not previously been established [29], in this study we also found no differences between the age groups of the Latin American population. A recent national-wide report on the Argentine population showed an increased fear, anxiety, and depression at the beginning of the quarantine that affected people under 29 years old [30]. On the other hand, our findings have shown differences in the level of fear between genders in all countries coinciding with previous studies in the Cuban population affecting mostly women [31] and may lead to the development of symptoms of anxiety and/or depressive disorder [32,33].

In addition, we observed heterogeneity in the fear scores between countries. In particular, Peru, Argentina, and Mexico showed high levels of fear, while more than half of the participants in Bolivia, Mexico, and Colombia showed moderate levels of fear. These results scrutinize our first hypothesis and could be subject to numerous country factors as personal (living conditions, health conditions, habits, etc.), as well as social (quarantine number, work condition, morbidity, and mortality of the country or region, presence of a relative or neighbor with COVID-19, the consumption of massive information [Infodemic] and, others, which were not addressed in this study) [34-36].

As has recently been demonstrated in some Latin American countries [37], the evaluation of fear has been restricted to the validation of the FCV-19S and no national-wide research has been carried out to understand population fear and differentiated by gender and age. In fact, in Brazil, Peru, Mexico and Argentina no differences between genders have been previously reported [37-39]. There is the possibility that the mental affectations are more settled in women during the pandemic, and a higher workload, pay gaps, and family and work burden are factors that have led to a greater crisis for women during COVID-19 [40,41]. In this study, we estimated the level of fear by gender, and Latin American women have a higher level of fear. This fear may be the result of certain factors and may have a negative impact on mental health.

As part of the second hypothesis, we can confirm that the degree of fear between Peru and Mexico were different compared to Spain (comparison group with 14-16 FCV-S19 score) [37]. For Spain, only $4 \%$ of the participants had a high level of fear of COVID-19, showing direct differences with Mexico and Peru (Figure 1). However, in Spain it has also been seen that almost half of the participants have very high levels of fear and concern related to the fact that a family member may die from COVID-19, there was even a fear of the spread of the virus in around 40\% [42]. Just as there are differences in the management of the response to COVID-19 between regions and countries, the impact on the mental health of populations may be subject to the successful outcome of these measures [43].

Although high levels of fear have been reported among Peruvians [44], this estimate has not been made with the FCVS19, making its multi-population comparison difficult [37]. Since the beginning of the pandemic, the Peruvian population has been subject to protection against SARS-CoV-2 [45] but only at the end of the first wave have interventions in mental health been developed. Our results are the first evaluation of fear in the general Peruvian population where a significant number of people have been described as afraid or very afraid of the COVID-19.

This study had limitations. The first limitation is the entire sample size because we conducted a study during the first wave of COVID-19 in Latin America. Therefore, due to lockdown reasons, there were limitations to enrolling participants. Second, although these low fear scores could explain also why COVID-19 prevention and control strategies have not had the 
expected results, we acknowledge that the findings of our study may not be generalized since massive studies are required to clarify the nature of fear of COVID-19 among Latin American populations, which should be considered in future research.

In conclusion, our findings show that fear of COVID-19 vary among Latin American, and also, there was a large number of populations with low levels of fear in all countries showing differences (Peru and Mexico) compared to a European country (Spain) during the spread of COVID-19 in 2020. The present study provides important information on the fear scores in the Latin American population; also, it helps to fill this gap in knowledge by providing evidence from government institutions to improve public health strategies for prevention and treatment of mental disorders among Latin American communities.

Author contributions: JMS provided the study concept and design statistical analysis, data management, and wrote the manuscript. BC provided the design, data acquisition, formal analysis, and performed data management. HCP provided the study concept, statistical analysis, data analysis and interpretation, and wrote the article. All authors approved the final version to be published.

Funding: No funding source is reported for this study.

Declaration of interest: No conflict of interest is declared by authors. Availability of data and material: The datasets used and analyzed during the current study are available from the corresponding author on reasonable request.

\section{REFERENCES}

1. Burki T. COVID-19 in Latin America. Lancet Infect Dis. 2020;20(5):547-8. https://doi.org/10.1016/S1473-3099(20) 30303-0

2. Rodriguez-Morales AJ, Gallego V, Escalera-Antezana JP, Méndez CA, Zambrano LI, Franco-Paredes C, et al. COVID19 in Latin America: The implications of the first confirmed case in Brazil. Travel Med Infect Dis. 2020;35:101613. https://doi.org/10.1016/j.tmaid.2020.101613 PMid:32126292 PMCid:PMC7129040

3. Lewnard JA, Lo NC. Scientific and ethical basis for socialdistancing interventions against COVID-19. Lancet Infect Dis. 2020;20(6):631-3. https://doi.org/10.1016/S14733099(20)30190-0

4. Fernandes N. Economic Effects of Coronavirus Outbreak (COVID-19) on the World Economy. New York: SSRN; 2020. https://doi.org/10.2139/ssrn.3557504

5. Román MPD, Partido O, Jaramillo MC. Alternative reflections on the treatment of violence and crime in Latin America: the prevention of crime as a strategy. Social Med. 2019;12(2):102-8.

6. Andrade EF, Pereira LJ, Luiz de Oliveira AP, et al. Perceived fear of COVID-19 infection according to sex, age and occupational risk using the Brazilian version of the Fear of COVID-19 Scale. Death Studies, 2020;26:1-10. https://doi. org/10.1080/07481187.2020.1809786 PMid:32845795

7. Cyn-Young P, Kim K, Roth S. Global shortage of personal protective equipment amid COVID-19: Supply chains, bottlenecks, and policy implications. Philippines: ADR. 2020. https://doi.org/10.22617/BRF200128-2

8. Kobayashi T, Jung S, Linton NM, Kinoshita R, Hayashi K, Miyama T, et al. Communicating the Risk of Death from Novel Coronavirus Disease (COVID-19). J Clin Med. 2020;9(2):580. https://doi.org/10.3390/jcm9020580 PMid: 32098019 PMCid:PMC7073841
9. Litewka SG, Heitman E. Latin American healthcare systems in times of pandemic. Dev World Bioeth. 2020;20(2):69-73. https://doi.org/10.1111/dewb.12262 PMid:32282974 PMCid:PMC7262025

10. Campbell AM. An Increasing Risk of Family Violence during the Covid-19 Pandemic: Strengthening Community Collaborations to Save Lives. Forensic Sci Int Rep. 2020;2:100089. https://doi.org/10.1016/j.fsir.2020.100089 PMCid:PMC7152912

11. Sher L. COVID-19, anxiety, sleep disturbances and suicide. Sleep Med. 2020;70:124. https://doi.org/10.1016/ j.sleep.2020.04.019 PMid:32408252 PMCid:PMC7195057

12. Ahorsu DK, Chung-Ying L, Imani V, Saffari M, Griffiths MD, Pakpour AH. The Fear of COVID-19 Scale: Development and Initial Validation. Int J Ment Health Addiction. 2020:1-9. https://doi.org/10.1007/s11469-020-00270-8

13. Cavalheiro FRS, Sticca MG. Adaptation and Validation of the Brazilian Version of the Fear of COVID-19. Int J Ment Health Addiction. 2020:1-9. https://doi.org/10.1007/s11469-02000415-9 PMid:33250672 PMCid:PMC7682694

14. Lin C-H, Hou W-L, Mamun MA, Aparecido da Silva J, BrochePérez Y, Ullah I, et al. Fear of COVID-19 Scale (FCV-19S) across countries: Measurement invariance issues. Nursing Open. 2021:1-17. https://doi.org/10.1002/nop2.855 PMid:33745219 PMCid:PMC8186712

15. Mamun MA, Sakib N, Gozal D, Bhuiyan Al, Hossain S, Bodrud-Doza M, et al. The COVID-19 pandemic and serious psychological consequences in Bangladesh: A populationbased nationwide study. J Affect Disord. 2020;279:462-72. https://doi.org/10.1016/j.jad.2020.10.036 PMid:33120247 PMCid:PMC7568472

16. Giordani RCF, Giolo SR, Muhl C, Estavela AJ, Mabuie Gove JI. Validation of the FCV-19 Scale and Assessment of Fear of COVID-19 in the Population of Mozambique, East Africa. Psychol Res Behav Manag. 2021;14:345-54. https://doi.org/10.2147/PRBM.S298948 PMid:33776494 PMCid:PMC7989366

17. Alyami M, Henning M, Krägeloh CU, Alyami H. Psychometric Evaluation of the Arabic Version of the Fear of COVID-19 Scale. Int J Ment Health Addict. 2020:1-14. https://doi.org/10.1007/s11469-020-00316-x PMid:32427217 PMCid:PMC7229877

18. Harper CA, Satchell LP, Fido D, Latzman RD. Functional Fear Predicts Public Health Compliance in the COVID-19 Pandemic. Int J Ment Health Addiction. 2020. https://doi.org/10.1007/s11469-020-00281-5 PMid:32346359 PMCid:PMC7185265

19. Reznik A, Gritsenko V, Konstantinov V, Khamenka N, Isralowitz R. COVID-19 Fear in Eastern Europe: Validation of the Fear of COVID-19 Scale. Int J Ment Health Addict. 2020:1-6. https://doi.org/10.1007/s11469-020-00283-3

20. Satici B, Gocet-Tekin E, Deniz ME, Satici SA. Adaptation of the Fear of COVID-19 Scale: Its Association with Psychological Distress and Life Satisfaction in Turkey. Int J Ment Health Addiction. 2020. https://doi.org/10.1007/ s11469-020-00294-0

21. Caycho-Rodríguez T, Vilca LW, Cervigni M, Gallegos M, Martino P, Portillo N, et al. Fear of COVID-19 scale: Validity, reliability and factorial invariance in Argentina's general population. Death Studies. 2020:1-10. https://doi.org/ 10.1080/07481187.2020.1836071 PMid:33118860

22. Furman H, Griffiths MD, Pakpour AH, Simkin H. Evidence of Validity of the the Fear of COVID-19 Scale (FCV-19S) in the argentinian context. PSOCIAL. 2020;6(2):99-110. 
23. Cassiani-Miranda CA, Tirado-Otálvaro AF, Campo-Arias A. Adaptation and psychometric evaluation of the Fear of COVID-19 Scale in the general Colombian population. Death Study. 2021:1-8. https://doi.org/10.1080/ 07481187.2021.1874572 PMid:33464177

24. García-Reyna B, Castillo-García GD, Barbosa-Camacho FJ, Cervantes-Cardona GA, Cervantes-Pérez E, TorresMendoza BM, et al. Fear of COVID-19 scale for hospital staff in regional hospitals in Mexico: A brief report. Int J Ment Health Addiction. 2020:1-10. https://doi.org/10.1007/ s11469-020-00413-x PMid:33169075 PMCid:PMC7640993

25. Huarcaya-Victoria J, Villarreal-Zegarra D, Podestà A, LunaCuadros MA. Psychometric Properties of a Spanish version of the fear of COVID-19 scale in general population of Lima, Peru. Int J Ment Health Addiction. 2020:1-9. https://doi.org/10.1007/s11469-020-00354-5 PMid:32837434 PMCid:PMC7307940

26. Moya-Salazar J, Cañari B, Sevillano-Jimenez J, ContrerasPulache H. Validation of Fear of COVID-19 Scale (FCV-19S) questionnaire in undergraduate students: the fear of COVID-19 survey. Rev Invest Universidad Norbert Wiener. 2021;10(2). https://doi.org/10.12688/f1000research.51400.1

27. Fitzpatrick KM, Harris C, Drawve G. Fear of COVID-19 and the mental health consequences in America. Psychol Trauma. 2020;12(S1):S17-S21. https://doi.org/10.1037/ tra0000924 PMid:32496100

28. Doshi D, Karunakar P, Sukhabogi JR, Prasanna JS, Mahajan SV. Assessing Coronavirus Fear in Indian Population Using the Fear of COVID-19 Scale. Int J Ment Health Addict. 2020:1-9. https://doi.org/10.1007/s11469-020-00332-x PMid:32837422 PMCid:PMC7255701

29. Soraci P, Ferrari A, Abbiati FA, Del Fante E, De Pace R, Urso $A$, et al. Validation and psychometric evaluation of the Italian version of the Fear of COVID-19 Scale. Int J Ment Health Addiction. 2020:1-10. https://doi.org/10.1007/ s11469-020-00277-1 PMid:32372892 PMCid:PMC7198091

30. Universidad de Buenos Aires. Crisis de coronavirus Estudio $N^{\circ} 8.70$ días de cuarentena: salud mental, economía y gestión política. Buenos Aires: Facultad de Piscología, Universidad de Buenos Aires; 2020.

31. Broche-Pérez Y, Fernández-Fleites Z, Jiménez-Puig E, Fernández-Castillo E, Rodríguez-Martin BC. Gender and Fear of COVID-19 in a Cuban Population Sample. Int J Ment Health Addiction. 2020:1-9. https://doi.org/10.1007/ s11469-020-00343-8

32. Panchal N, Kamal R, Follow CC. The implications of COVID19 for mental health and substance use. Available at: https://www.kff.org/coronavirus-covid-19/issue-brief/theimplications-of-covid-19-for-mental-health-andsubstance-use/

33. Srivastava A, Bala R, Srivastava AK, et al. Anxiety, obsession and fear from coronavirus in Indian population: a webbased study using COVID-19 specific scales. Int J Community Med Public Health. 2020;7(11):4570-7. https://doi.org/10.18203/2394-6040.ijcmph20204763
34. Garcia PJ, Alarcón A, Bayer A, Buss P, Guerra G, Ribeiro H, et al. COVID-19 Response in Latin America. Am J Trop Med Hyg. 2020;103(5):1765-72. https://doi.org/10.4269/ajtmh. 20-0765 PMid:32940204 PMCid:PMC7646820

35. Mertens G, Gerritsen L, Duijndam S, Salemink E, Engelhard IM. Fear of the coronavirus (COVID-19): Predictors in an online study conducted in March 2020. J Anx Dis. 2020;74:102258. https://doi.org/10.1016/j.janxdis.2020.102 258 PMid:32569905 PMCid:PMC7286280

36. Berberoglu A, Dinler A. The mediating role of communication on COVID-19 in the relationship between media hype and generated fear: case of North Cyprus. J Clin Exp Invest. 2021;12(1):em00759. https://doi.org/10.29333/ jcei/9281

37. Luo F, Ghanei Gheshlagh R, Dalvand S, Saedmoucheshi S, Li Q. Systematic Review and Meta-Analysis of Fear of COVID-19. Front Psychol. 2021;12:661078. https://doi.org/ 10.3389/fpsyg.2021.661078 PMid:34177712 PMCid: PMC8231929

38. Rodríguez-Hidalgo AJ, Pantaleón Y, Dios I, Falla D. Fear of COVID-19, Stress, and Anxiety in University Undergraduate Students: A Predictive Model for Depression. Front Psychol. 2020;11:591797. https://doi.org/10.3389/fpsyg.2020.591 797 PMid:33224080 PMCid:PMC7674167

39. Giordani RCF, Zanoni da Silva M, Muhl C, Giolo SR. Fear of COVID-19 scale: Assessing fear of the coronavirus pandemic in Brazil. J Health Psychol. 2020 Dec 16:1359105320982035. https://doi.org/10.1177/1359105320982035 PMid:33327789

40. Alon T, Doepke M, Olmstead-Rumsey J, Tertilt M. The Impact of COVID-19 on Gender Equality. San Diego; UC San Diego Press; 2020. https://doi.org/10.3386/w26947

41. Wenham C, Smith J, Morgan R; Gender and COVID-19 Working Group. COVID-19: the gendered impacts of the outbreak. Lancet. 2020 Mar 14;395(10227):846-8. https://doi.org/10.1016/S0140-6736(20)30526-2

42. Sandín B,Valiente RM, García-Escalera J, Chorot P. Impacto psicológico de la pandemia de COVID-19: Efectosnegativosy positivos en población española asociados al periodode confinamiento nacional. Rev Psicopatol Psicol Clin. 2020;5(1):1-22. https://doi.org/ 10.5944/rppc.27569

43. Anderson RM, Heesterbeek $H$, Klinkenberg D, Hollingsworth TD. How will country-based mitigation measures influence the course of the COVID-19 epidemic? Lancet, 2020;395:931-4. https://doi.org/10.1016/S01406736(20)30567-5

44. Mejia CR, Rodriguez-Alarcon JF, Vera-Gonzales JJ, PonceLopez VL, Chamorro-Espinoza SE, Quispe-Sancho A, et al. Perception of fear of the COVID-19 pandemic in Peru. Electron J Gen Med. 2021;18(3):em285. https://doi.org/10.29333/ejgm/9764

45. Moya-Salazar J, Cañary B, Zuñiga N, Jaime-Quispe A, RojasZumaran V, Contreras-Pulache $\mathrm{H}$. Deaths, infections, and herd immunity in the COVID-19 pandemic: A comparative study of the pandemic control strategies implemented in Peru and the United Kingdom. Rev Fac Med. 2022;70(2): e92823. https://doi.org/10.15446/revfacmed.v70n2.92823 